\title{
Removal of pacemaker leads in extracorporeal circulation
}

\author{
E Likaj;, A Kacani, S Dumani, D Hasi, A Alia, A Kenga, L Dibra, A Refatllari \\ From 23rd World Congress of the World Society of Cardio-Thoracic Surgeons \\ Split, Croatia. 12-15 September 2013
}

\section{Background}

The value of extraction of infected or hazardous endocardial pacemakers leads is well established. This review describes our experience with safe and open technique.

\section{Methods}

We reviewed our registry in a period of 20 years (1992 2012). We found four patients with pacemaker leads removal in median sternotomy and extracorporeal circulation.

\section{Results}

Overall, 6 leads were removed from 4 patients. The commonest indication for extraction was infection (endocarditis) in three patients $(75 \%)$. The other patient was operated because of massive thrombus on the leads. Removal was complete and safe for all the patients. All the patients received epicardial lead with pacemaker pocket located in the rectus abdominis muscle. The postoperative period was free of complications in all the patients.

\section{Conclusions}

Pacemaker infections generally respond to antibiotics and complete hardware removal. However, these principles cannot always be invoked, and the risk of complications is likely to increase when hardware cannot be completely removed. Open lead extraction is an aggressive but safe technique in cases of infected patients with endocarditis unresponsive to antibiotic therapy.
Published: 11 September 2013

doi:10.1186/1749-8090-8-S1-P155

Cite this article as: Likaj et al.: Removal of pacemaker leads in extracorporeal circulation. Journal of Cardiothoracic Surgery 2013 8(Suppl 1):P155.

* Correspondence: ermallikaj@yahoo.com

Cardiovascular Surgery Department, University Hospital Centre "Mother

Theresa", Tirana, Albania

Submit your next manuscript to BioMed Central and take full advantage of:

- Convenient online submission

- Thorough peer review

- No space constraints or color figure charges

- Immediate publication on acceptance

- Inclusion in PubMed, CAS, Scopus and Google Scholar

- Research which is freely available for redistribution
() Biomed Central 